\title{
Paleoproterozoic granitic magmatism and associated sedimentary basin from the Susong complex zone in the Dabie orogen, China
}

\author{
ZHENG WU, YANG YANG AND YI-CAN LIU
}

School of Earth and Space Sciences, University of Science and Technology of China

Presenting Author: slugger@mail.ustc.edu.cn

The Dabie orogen in the middle part of the Qinling-DabieSulu orogenic belt of China is formed by the northward subduction of the South China Block beneath the North China Block in the Triassic and exposed the largest area of UHP rocks in the world $[1,2,3]$. It consists of a series of fault-bounded rock units with various metamorphic grades and evolutional histories $[3,4]$. Among of them, the Susong complex zone (SZ) is a relatively low-grade metamorphic unit located in the southern part of the Dabie orogen. It mainly consists of garnet-micaquartz schist, granitic gneiss, quartzite, marble, meta-sandstone, graphite schist and phosphate rock series with subordinate metabasalt/garnet amphibolite, meta-gabbro, rodingite and metaserpentinite.

This study performed whole-rock element geochemistry, and zircon SHRIMP U-Pb dating and Hf isotope analyses on granitic gneisses, meta-rhyolitic tuffs and meta-sandstones from the SZ. The results reveal that: (1) the protolith ages for the studied granitic gneiss and meta-rhyolitic tuffs are $\sim 2.0 \mathrm{Ga}$, and their precursors were derived from remelting of the Neoarchean basement rocks with epidote-amphibolite facies metamorphic overprinting in the late Triassic; (2) The zircons from metasandstones are mainly composed of Paleoproterozoic magmatic origin with a few Neoarchean inherited zircons, indicating that the meta-sandstones' source area were the coeval Paleoproterozoic magmatic rocks and thus their sedimentary age should be $\sim 2.0 \mathrm{Ga}$. In this regard, the formational tectonic setting of the precursors for the meta-sandstones and coexisting metarhyolitic tuffs here were closely related to those of the granitic gneisses. Combined with the whole-rock element and $\mathrm{Hf}$ isotope analysis, therefore, these new data provide for the first time solid constraints on the Paleoproterozoic $(2.0 \mathrm{Ga})$ arc-continent collision, and related granitic magmatism and basin sediments in the northern margin of the South China Craton.

This study was financially supported by the National Basic Research Program of China (2015CB856104) and the National Natural Science Foundation of China (41273036 and 42072059).

[1] Xu et al. (1992) Science 256, 80-82. [2] Li et al. (1993) Chem Geol 109, 89-111. [3] Liu et al. (2017) J Asian Earth Sci 145, 74-90. [4] Li et al. (2020) Gondwana Res 78, 1-19. 